\title{
Developing Database System for Managing Medical Insurance Claims in the Human Resource Department
}

\author{
Salma Eka Ramadhany ${ }^{1}$, Hery Hamdi Azwir*2 \\ ${ }^{1,2)}$ Faculty of Engineering, Industrial Engineering Department, President University \\ Jl. Ki Hajar Dewantara, Kota Jababeka, Cikarang, Bekasi - Indonesia 17530 \\ Email: rmdhany.1998@gmail.com ${ }^{1}$, hery.azwir@president.ac.id ${ }^{2 *}$
}

DOI: 10.20961/performa.19.2.43965

\begin{abstract}
PT. X Indonesia provides medical insurance for their employee from BPJS Kesehatan and other private company insurance. Currently, the data management of medical insurance members is not efficient and effective because the data regarding medical insurance are managed manually using MS Excel. The manual process leads to incorrect data input and causes a delay in the process of getting treatment and reimbursement claim process. The company will reimburse the payment but the process is long and complicated because the company should check the limitation for reimbursement claims per year. To solve the problem, database systems are constructed using System Development Life Cycle (SDLC) methodology which consists of five phases; systems planning, systems analysis, systems design, systems implementation, and system test, and deployment. The business process flow diagram of the current and proposed system is analyzed. After that, user requirements are determined. The data flow diagram and entity-relationship diagram (ERD) is constructed. And the system is developed using MS Access. Finally, the system is deployed. The result is an application running in MS Access that can manage medical insurance claim more efficiently and effectively, compare to previous MS Excel.
\end{abstract}

Keywords: BPJS Kesehatan (Badan Penyelenggara Jaminan Sosial), Company Insurance, Database, System Development Life Cycle (SDLC), Data Flow Diagram, Entity Relationship Diagram.

\section{Introduction}

PT. $\mathrm{X}$ is known as a manufacturer of locally produced flexible packaging. They make packaging for many of the world's favorite brands, helping to shape the experience of all kinds of products that consumers choose, use, and depend on every day. The company has around 1500 employees. The Human Resource (HR) department handles all employees at Cikarang factory. As a well-managed company, they are concern really about employee health issues. Hence, they provide medical insurance for employees by Badan Penyelenggara Jaminan Sosial (BPJS), which is mandatory by the regulation, and another private insurance company. Medical insurance is not only for the employee itself but also for the employee's family member. The HR department in the company records all data of medical insurance members. Every month they need to handle any reports regarding sick employees and problems related to medical insurance.

Human resource staffs manage the medical insurance data and reimbursement claims from every employee. Some activities proceeded by the HR Department related to the medical insurance recording are to add employee data, add family member data, edit or delete data, reimbursement claim, billing statement, historical reports such as sorting today's data update. But unfortunately, all these data are managed manually by MS Excel only. There is no information system available that will support them.

According to (Buzkan, 2016) a Human resource information system (HRIS) is a system used to input, retrieve data, store, and analyze data related to the organization's human resources. The data could consist of salary, compensation insurance, leave, performance appraisal, employee benefits, etc. The HRIS can provide an output that is under the requirements of the use of resources with efficient and effective processes for the needs of the development of the overall business organization and the ability to achieve competitive advantage. It has been shown to

${ }^{*}$ Corresponding author 
improve the quality of products and services, lower costs, and make businesses function faster. (Khosravi, 2016). Therefore, the problem of increasing business process capabilities, business process reengineering, business process management, and business process improvement approaches provide a variety of models, methods, and techniques designed for developing business processes (Zemguliene \& Zemguliene, 2018).

Process mapping is a collection of instruments and methods used to understand an organization and its processes. Such tools allow us to track, evaluate, develop, streamline, and change business processes to realize efficiencies in organizations. A process map is a visual aid to visualize job processes that illustrate how inputs in which tasks are interconnected and highlights the steps taken to reliably achieve the desired result. A graphical representation of a phase is a flow diagram or flow map. Generally, the steps in the method are explained in a set of certain symbols that express 'what' or 'where' something happens. (Halseth, 2017)

Currently, the company manages health insurance through MS Excel, the process is still mostly done manually. This manual data processing, although using MS Excel, has contributed to many errors in data input and processing such as incorrectly entering the KTP number, employee name, family member, date of birth, etc. so that employees cannot seek treatment using health insurance. Therefore, employees will complain to the company which results in delays which will take around 1-3 weeks in the process because the health insurance provider requires confirmation from the company regarding the wrong input data.

Regarding the complaint, the procedure is the patient has to fill in complaint forms about personal data and sick problems before treatment can proceed. Then, a confirmation is required from the company, thus patients have to wait to be registered to receive treatment. In many cases, sick people have to be treated immediately, especially for urgent conditions such as accidents. For that situation, employees must pay full for treatment that should be covered by the insurance company so that they can be treated immediately. This incident caused employees to be dissatisfied and feel burdened.

Therefore, to improve the current medical insurance manual data processing, it is very urgent to develop an information system or at least a database system that can minimize, detect, prevent any error in data entry. The information system will automate any data processing that was previously executed manually.

\section{Methods}

The initial observation is done by identifying the problem in the inputted reimburse medical insurance process of the company. It turns out that there were frequent errors in entering health insurance reimbursement expenditure data which is quite time-consuming when checking reimbursement claim papers. This is because of many errors in the manual calculation of medical expenses on employees and forced HR to recalculate medical expenses. To overcome this problem, the design should provide menus for input reimbursement and reimbursement output or reports. When an employee requests a reimbursement, HR will inputs data into the reimbursement menu and saves the data then, the data will be stored in the reimbursement output, HR can check the reimbursement limit by looking for the employee ID or name in the search column and automatically calculating the employee reimbursement.

In order to develop such an information system, it is important to select the software development methodology. One of the basic methods is System Development Life Cycle (SDLC). In SDLC methodology, there are five fundamental phases in building an information system. There are system planning, system analysis, system design, system development, and system testing \& deployment. (Barjtya, Sharma, \& Rani, 2017) 


\subsection{System Planning}

System planning consists of information gathering and problem identification of the current system and needs of an enhanced system. Business process and document flow will be used to describe the current process and also proposes a system to be developed. In this phase, development tools and hardware requirements should be decided also. (Azwir \& Patriani, 2017)

\subsection{System Analysis}

The System Development Life Cycle (SDLC) is used to define the process and functions each system developer should perform without considering the tools they are using. The data flow diagram (DFD) visualized the connection in the program or system between different elements. DFD is a useful tool for high-level information visualization of a system by showing the way input data is processed via process sequence to the output effects. DFD is used by the system builder and others to visualize the existing system or another that might be necessary to satisfy the new need during the initial analysis stages. Systems analysts prefer to work with DFD, often when there is a need for a rich understanding of the boundaries between present systems and suggested systems. DFD consists of four main components: entities, processes, data stores, and data flow (Azwir \& Puspa, 2020).

\subsection{System Design}

Systems design is required to build an effective, reliable, and maintainable system. In this case, the system that will be designed is based on a database. To create a database systematically, an entity-relationship diagram (ERD), user interface design, input, and output design is created. Design is related to the user interface and database. Designing the user interface is one of the most important aspects because it is important to consider the user's convenience to run the system. To design the user interface, it is important to pay attention to the user requirements to fulfill the system objectives. (Sharma, 2017)

\subsection{System Development}

The development process is a critical process for the business process improvement since it will determine the success of the business process improvement. It will also determine the performance of the proposed system. Since the database is designed using MS Access, the software documentation will be formatted in MS Access. There are several formats in MS Excel that will be converted to the database. It also includes software documentation and a user manual. (Valacich \& George, 2017)

\subsection{System Testing and Deployment}

According to (Kendall \& Kendall, 2019). System Deployment will be proceeded after executing final system testing which is proceeded after completing the system development. The system has to be checked with test data and must pass the whole test plan which is based on the requirements. The test should include testing interfaces between subsystems, the correctness of output, invalid data entry test, and finally system documentation.

\section{Result and Discussion}

This section will explain the process according to the methods explained above. The discussion will show the business process flow chart of the current and proposed system, DFD, ERD, database design, User Interface Design, System Development, Testing, and Deployment.

\subsection{Business Process Flow Chart}

Figure 1 shows the business process of the current condition which is not effective and efficient. The current system has problems with the registration process of the employee to the 
medical facility which is the employees must pay for their treatment because of incorrect data input or data by the hospital server does not match with recorded data in the company.

Figure 2 shows the registration process of the proposed system that will improve by reducing mistakes in the data input process. This new system will minimize error in the input data, after employee registering by giving the required documents, the hospital able to directly proceed with registration with a document, match the data from the document to BPJS Kesehatan or Company Insurance database, and proceed with the medical insurance member for the treatment giving the queue number.

\subsection{Data Flow Diagram}

The data flow diagram (DFD) describes data processes and flows in the business system graphically. Through the structured analysis technique - DFD, graphical representation of data processes and flows can be explained throughout the organizations.

\subsubsection{Context Diagram}

The context diagram contains three entities, which are the HR Department, Employee, and Finance. The diagram also contains one process, which is Medical Insurance Information System. Employees do not have an output data flow because employees are not involved with MS Access application, it only occurs offline process activities that provide employee personal identity and reimbursement claim to the HR Department not involved in the process directly with the application. Figure 3 shows the context diagram level.

\subsubsection{DFD Level 0}

DFD level 0 explains in more detailed information about the process in the context diagram. Inputs and outputs in the context diagram will remain the same in DFD level 0. In DFD level 0 there are data stores, as shown in figure 4. In this case, the process of the Medical Insurance Data Management Database is extended into three more processes, which are CRUD [Create, Read, Update, and Delete] Database, Reimbursement Claim, Billing Statement, and Collecting the form (Offline Process). 


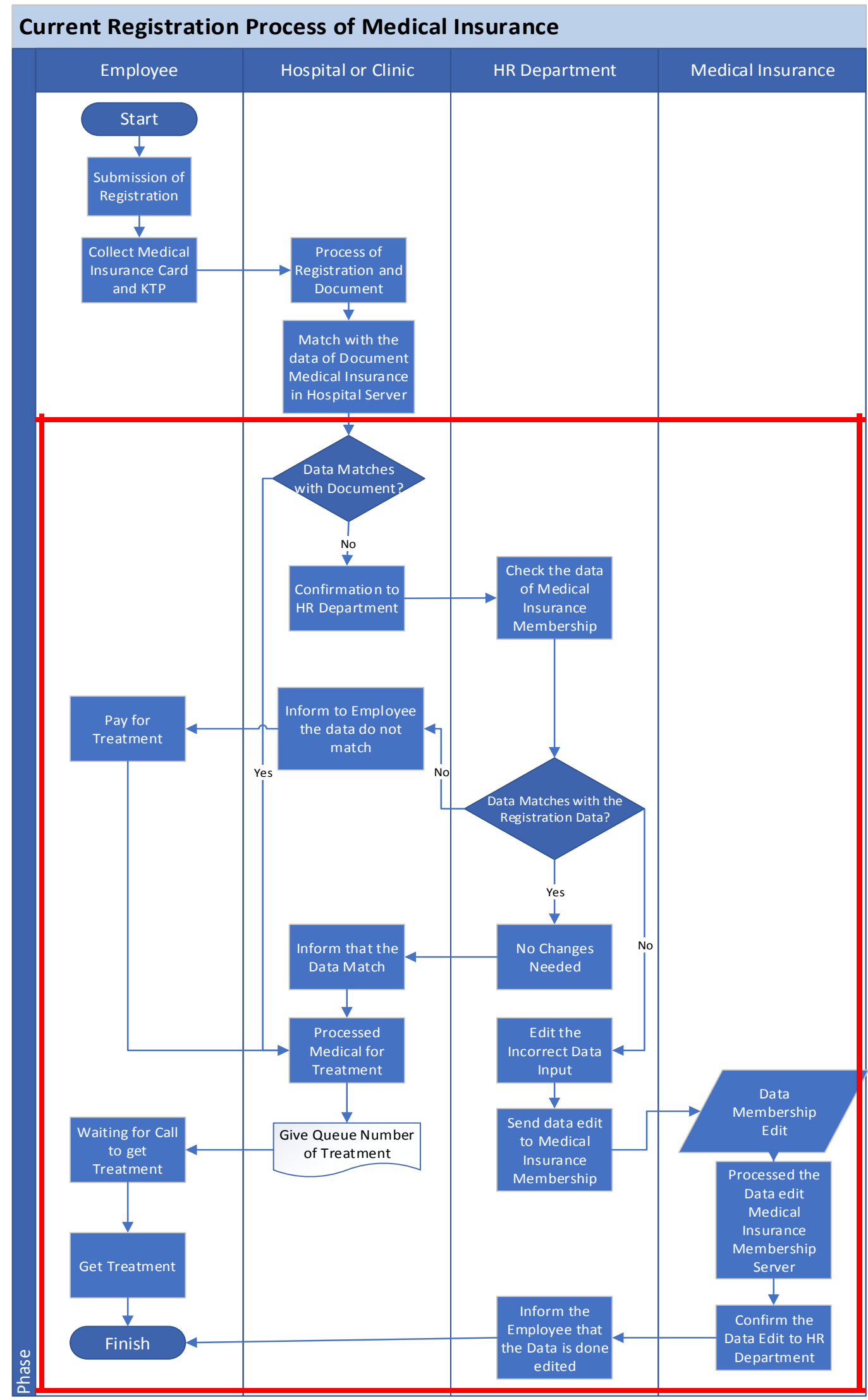

Figure 1. Business Process Flow Chart of Current System. 


\section{Proposed Registration Process of Medical Insurance}

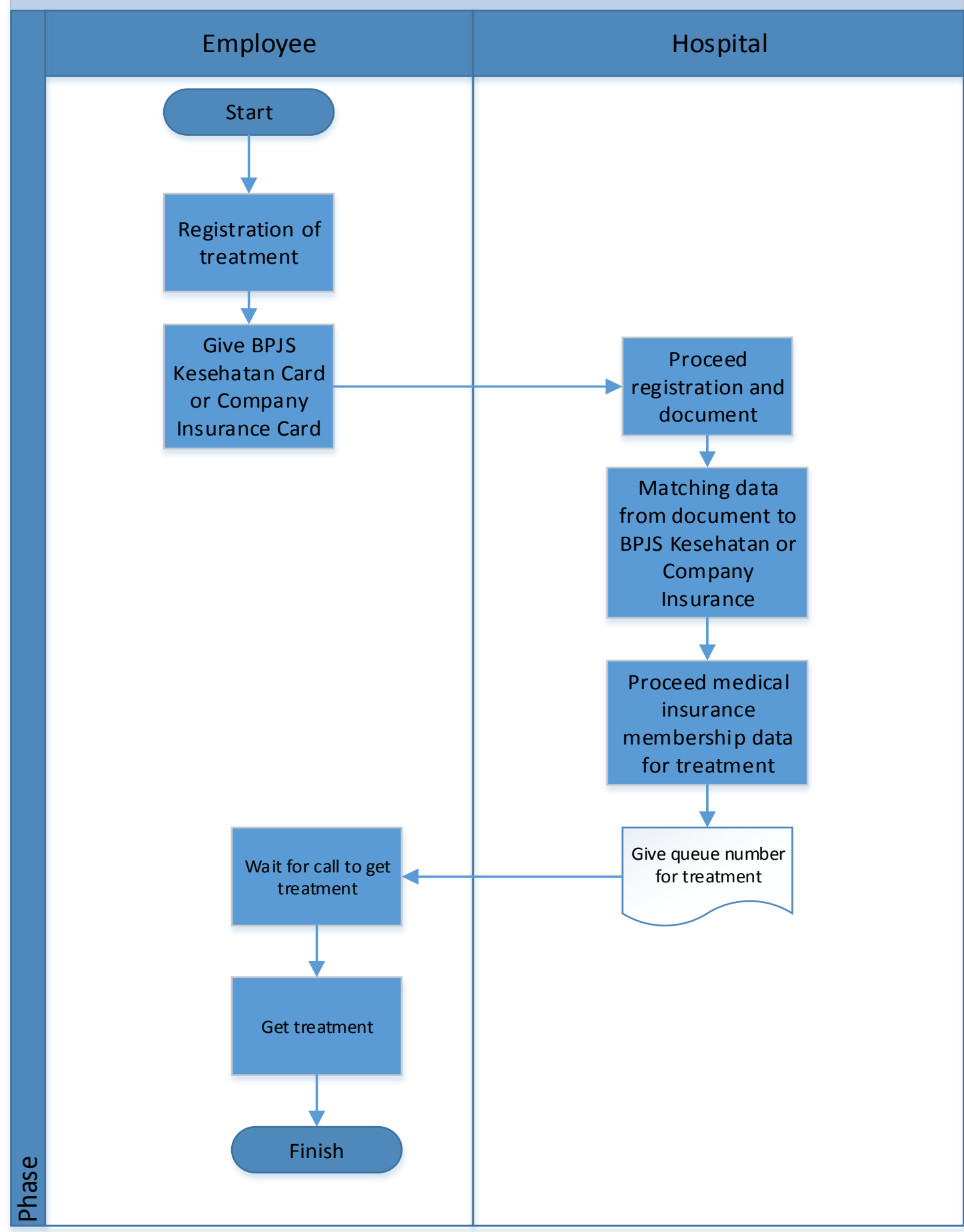

Figure 2. Business Process Flow Chart of Proposed System. 


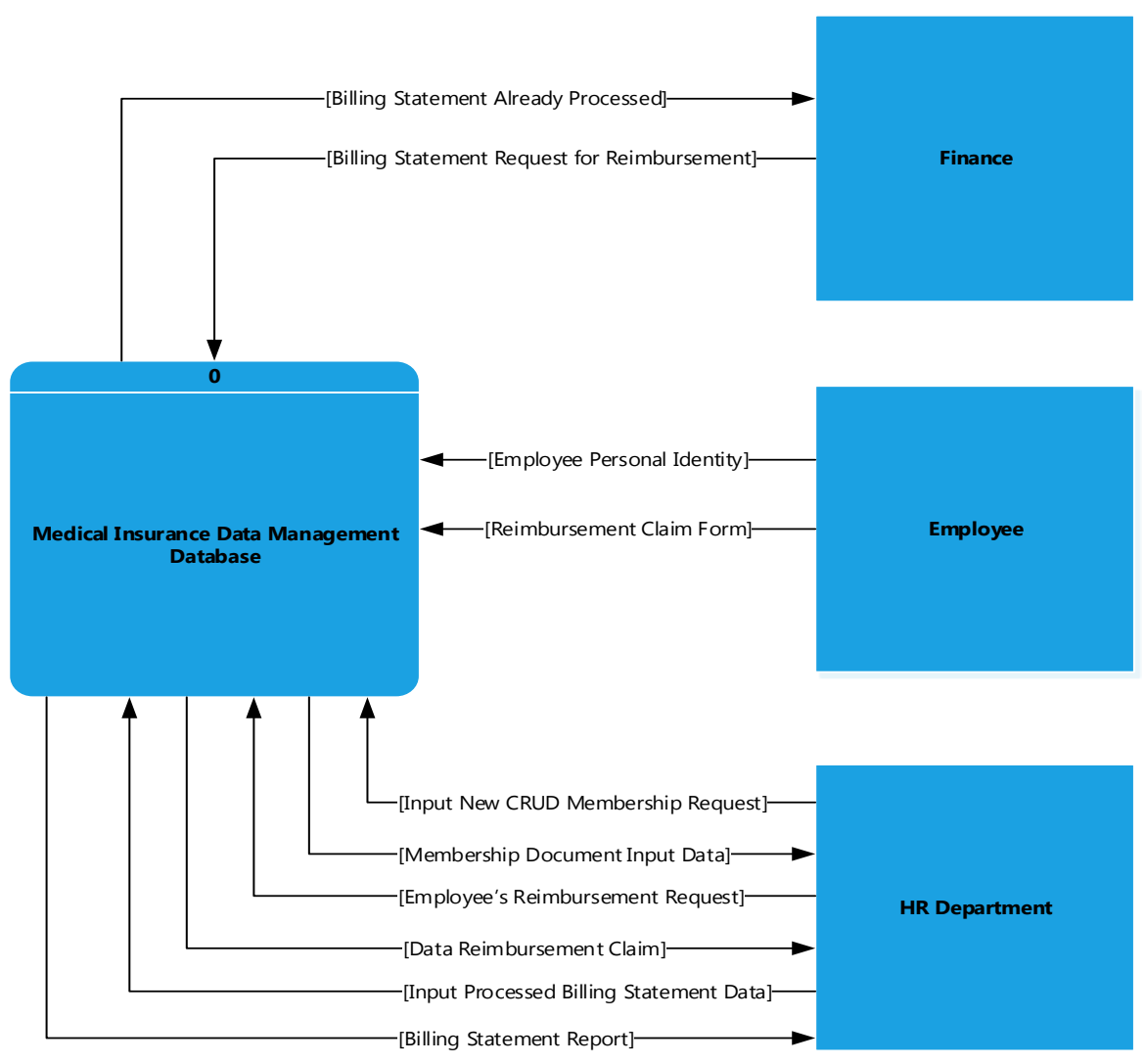

Figure 3. Context Level Diagram 


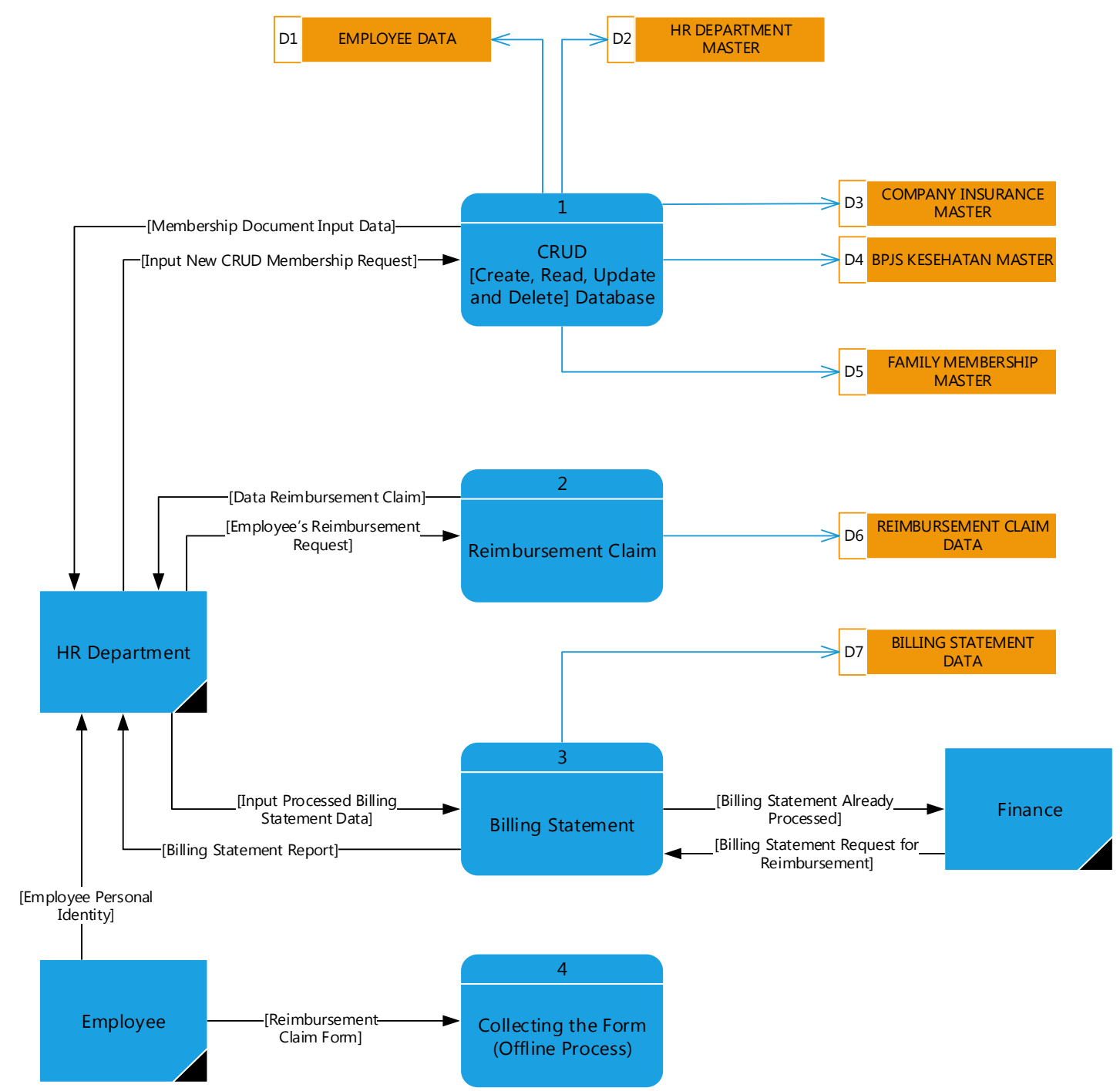

Figure 4. DFD Level 0

\subsubsection{DFD Level 1}

DFD level 1 explains more detailed information about the process in DFD level 0. The process in DFD level 0 is usually known as the parent process and the process in DFD level 1 is usually known as the child process. In this case, the DFD level 0 has three processes. Therefore, there will be three DFD level 1.

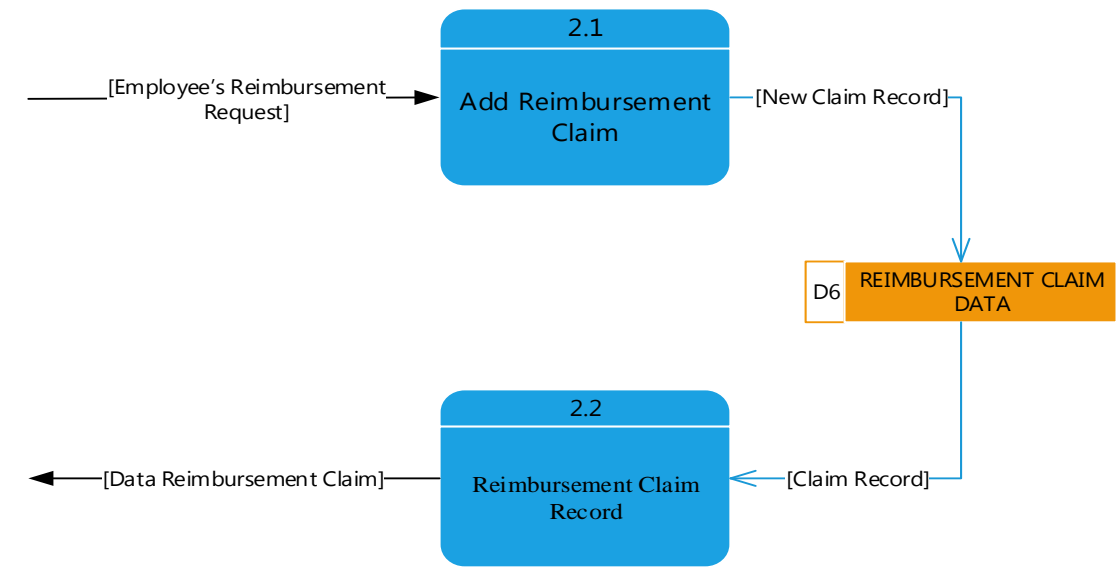

Figure 5. DFD Level 1 of Reimbursement Claim 
A. Reimbursement Claim

Reimbursement Claim in DFD Level 1 will explain how to process reimbursement in MS Access, as shown in figure 5.

\section{B. Billing Statement}

The billing statement in DFD Level 1 will explain how to process the billing statement report in MS Access, as shown in figure 6.

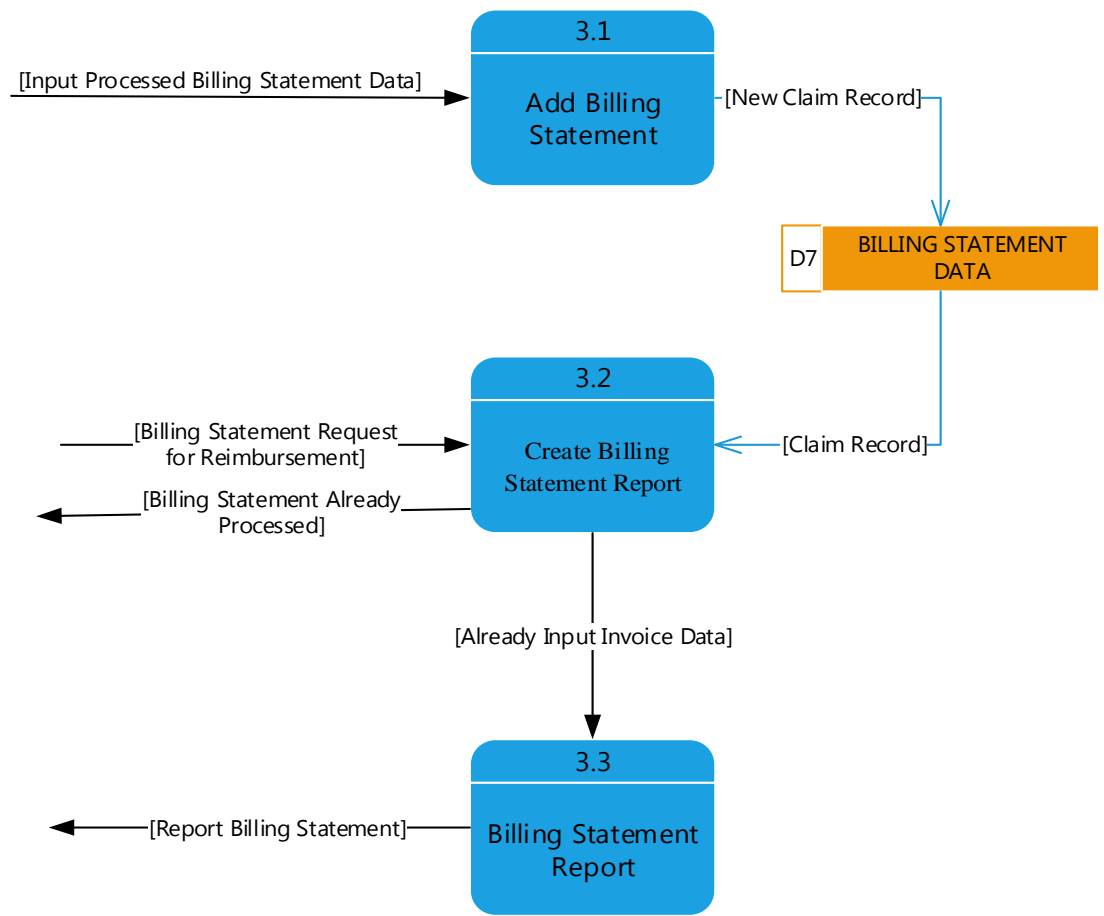

Figure 6. DFD Level 1 of Billing Statement

\subsection{Entity Relationship Diagram}

The entity-relationship diagram shows the entities and the relationships with each other in graphical representation. There are twelve entities and eleven relationships consist of the entityrelationship diagram of the Medical Insurance Data Management Database. The entities are Employee, Status, Jenis Kelamin, Status Kawin, Faskes, Faskes Dokter, Kelas Rawat, Kewarganegaraan, BPJS Family Membership, Edit, or Delete BPJS Kesehatan Data, Billing Statement, and Billing Details. Each entity has at least one relationship, as shown in figure 7.

\subsection{User Interface Design}

Designing the user interface is one of the most important aspects because it is important to consider the user's convenience to run the system. To design the user interface, it is important to pay attention to the user requirements to fulfill the system objectives.

\subsubsection{Login of Medical Services Data Management}

It can be seen that there is two fill-in login. Fill in "User ID" and "Password" to login. Only the HR Department admin can log in to the database. The "Login" of the "Medical Services Data Management Database", as shown in figure 8. 

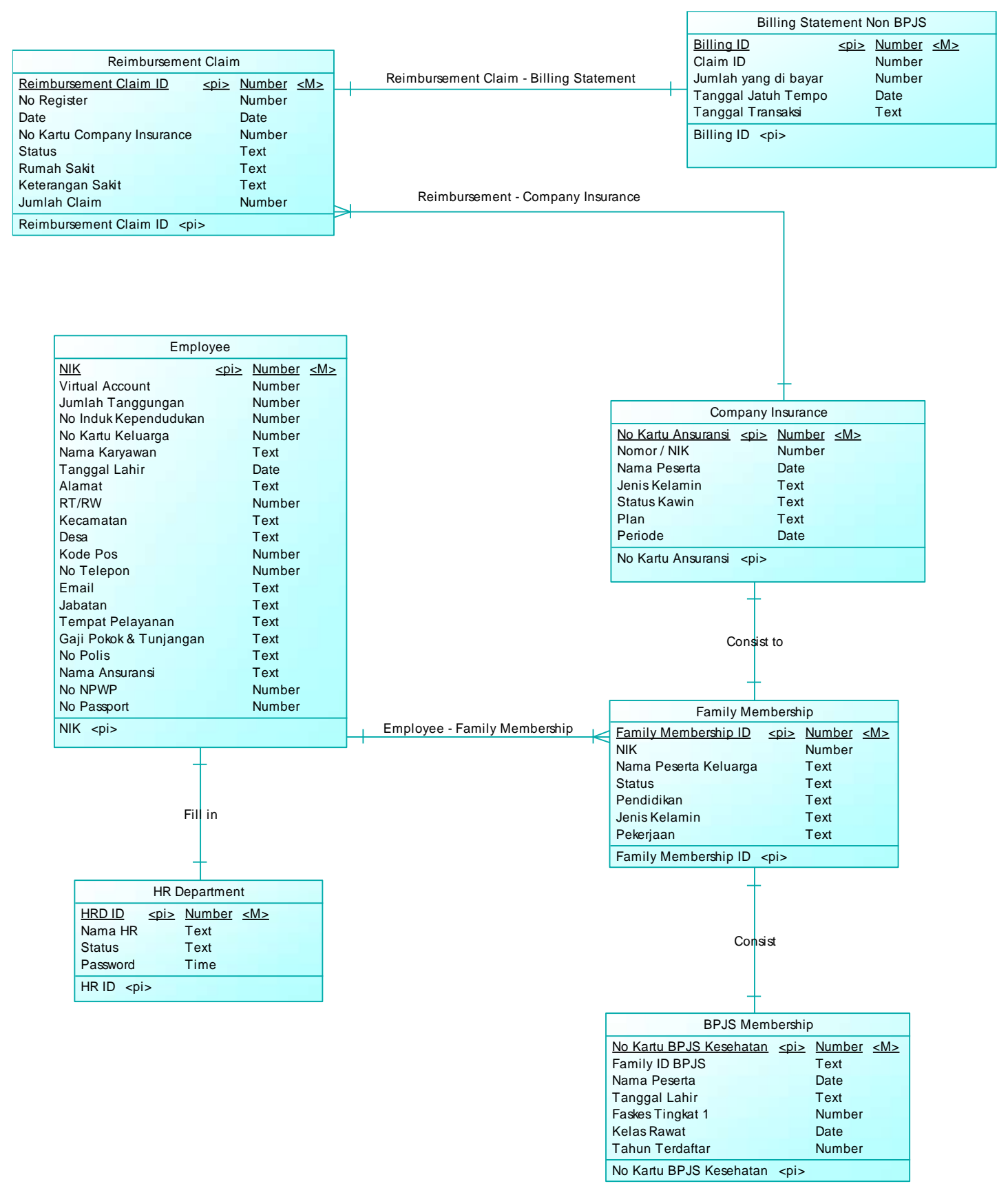

Figure 7. Entity Relationship Diagram 


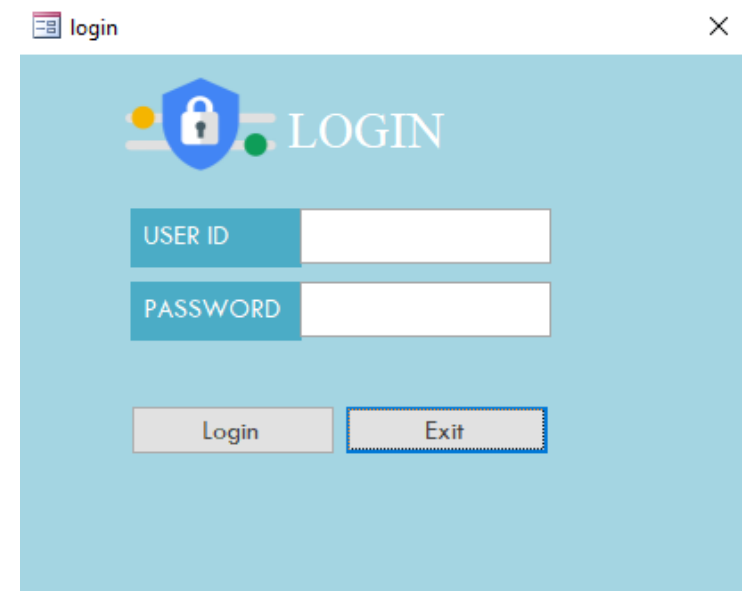

Figure 8. Login of Medical Services Data Management

\subsubsection{Main Menu of Medical Services Data Management}

It can be seen that eight menus inside the main menu available for database entry. The "Add Employee" menu is to open the form employee, "Add Family Membership" menu is to open the form new add family membership, "Company Insurance" menu is to open the form company insurance membership or non-BPJS, "BPJS Membership" menu is to open the form new add BPJS Kesehatan membership, "Reimbursement Claim" menu is to open the form fill reimbursement of employee claims from company insurance or non-BPJS, "Billing Statement" menu is to open the form fill billing statement claims. The "Report" menu is to access the stored data of billing statement medical insurance. And the "Log Out" menu is an exit from the database. The "Main Menu" of the "Medical Services Data Management Database" is shown in figure 9.

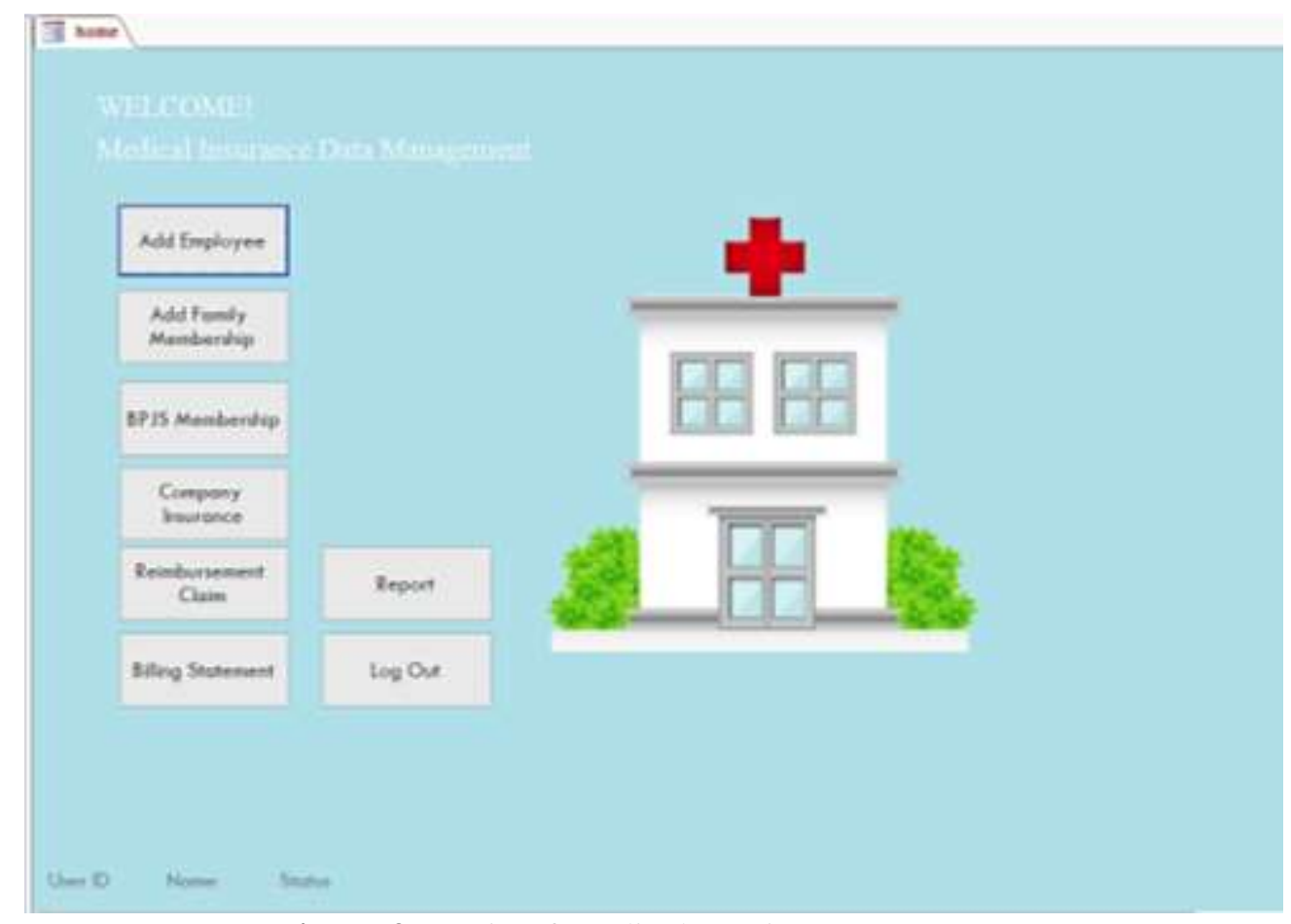

Figure 9. Login of Medical Services Data Management

\section{A. Input Design}

There are several inputs in the "Medical Services Data Management Database". All of the input menus can be seen in the menus. 


\section{- Add New Employee}

The purpose of "Add New Employee" is to add a new employee as a member of Medical Insurance to the database. The government obligates a company to register all of the employees to Medical Insurance below the company's name, as shown in figure 10.

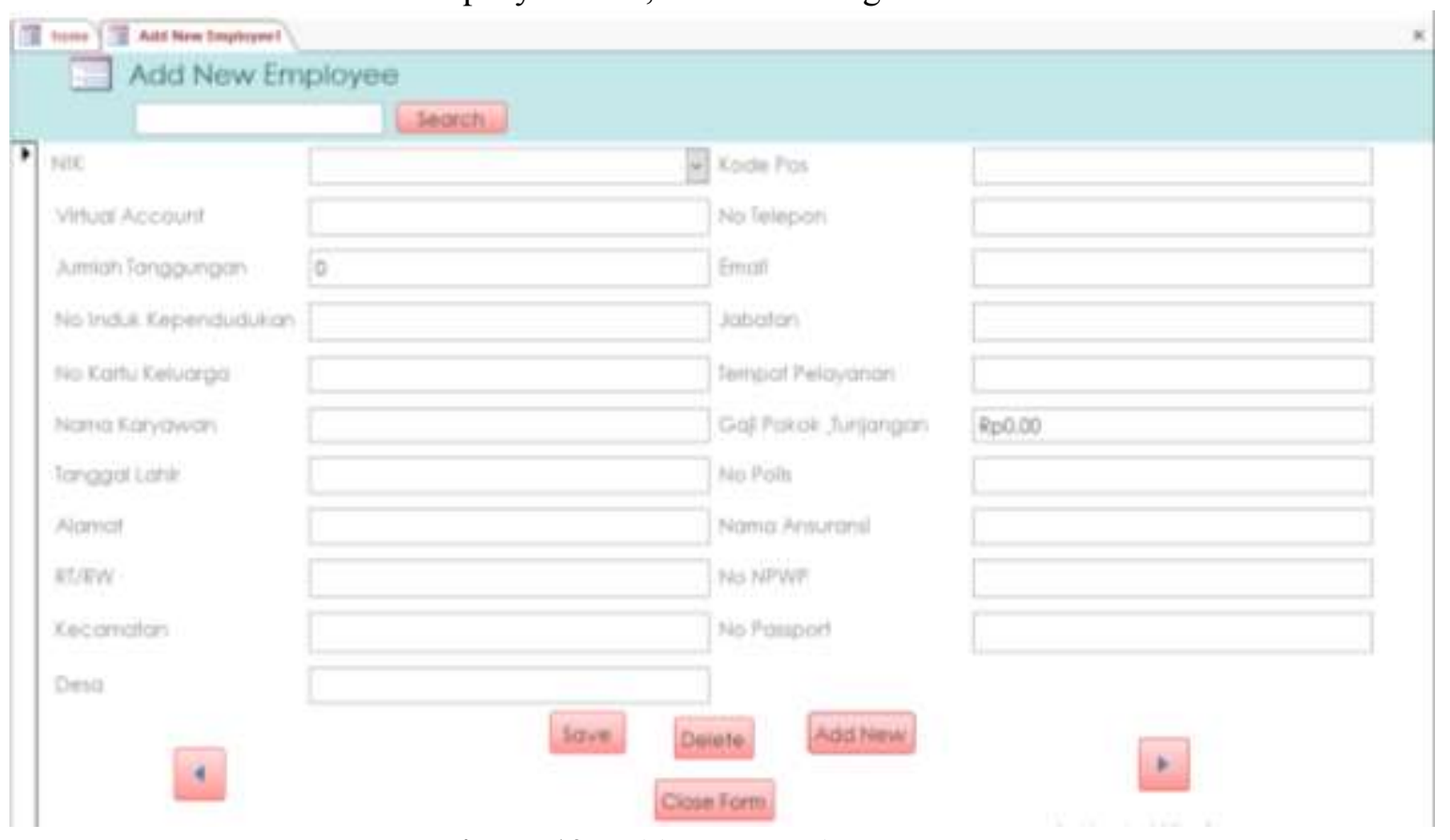

Figure 10. Add New Employee

\section{- Add New Family Membership}

The purpose of "Add New Family Membership" is to add a new family member as a member of Medical Insurance to the database. The employee has to register the family members to Medical Insurance, the employee may add one spouse and children. Therefore, this input is provided for an employee that wants to register the family members as Medical Insurance below the company's name. Figure 11 shows this menu.

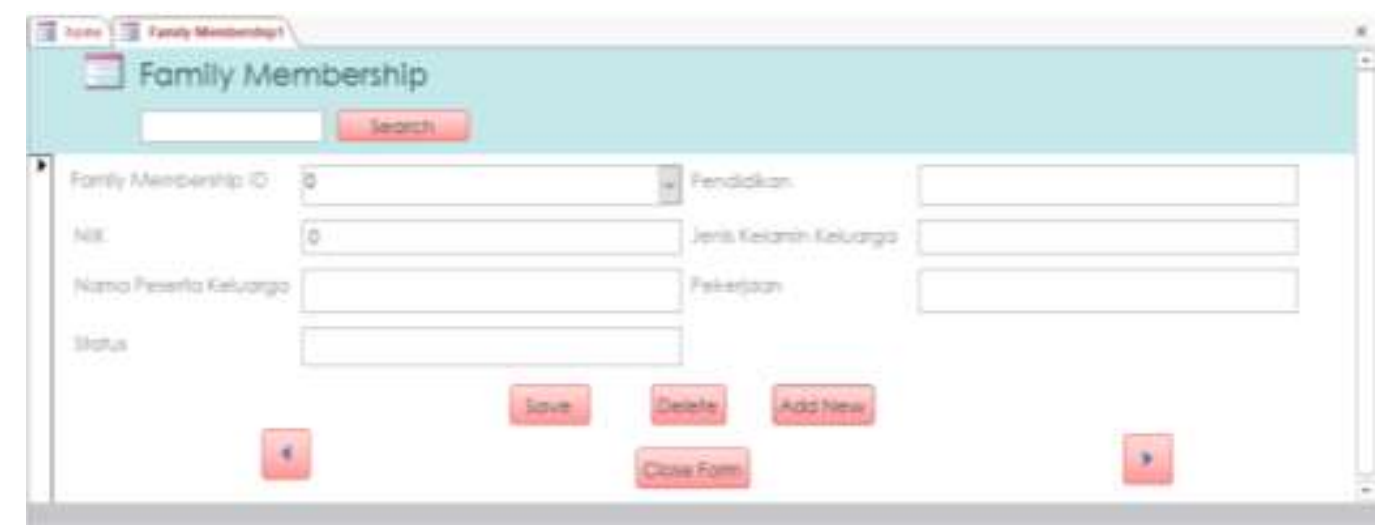

Figure 11. Add New Family Membership

\section{- Add New BPJS Membership}

The purpose of "Add New BPJS Membership" is to add the new employee as a member of BPJS Kesehatan to the database. Medical insurance from the government, the company provides BPJS insurance for employees. Therefore, this input is provided for employees that want to 
register themselves or the family members as the company insurance member. Figure 12 shows this menu.

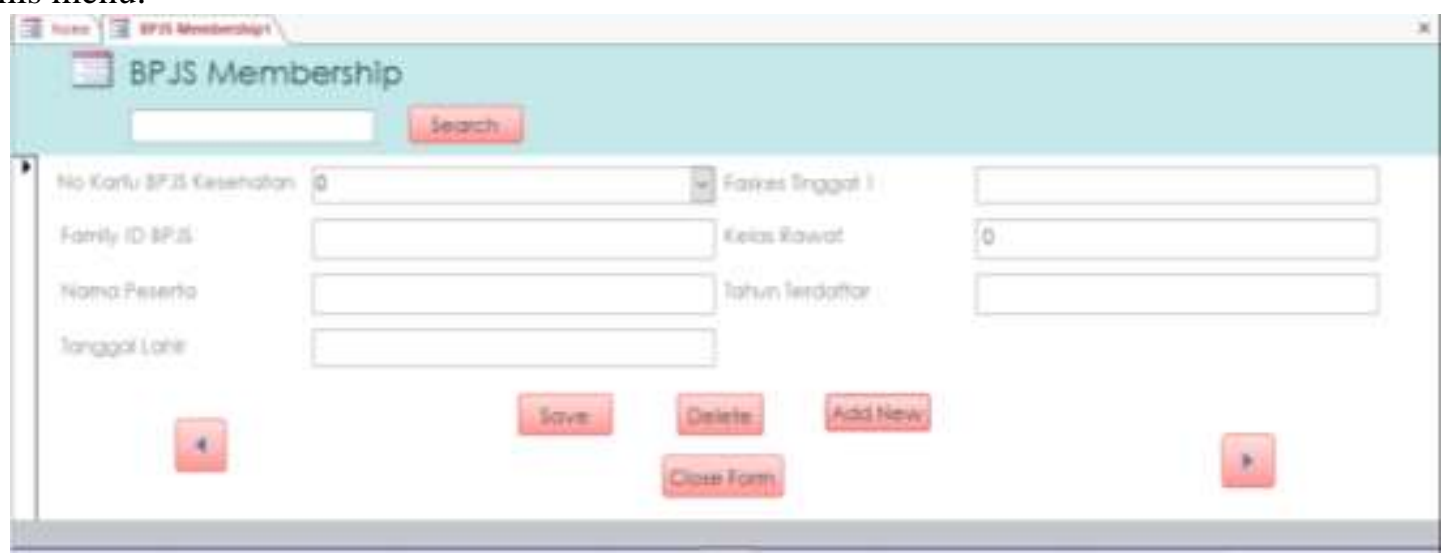

Figure 12. Add New BPJS Membership

\section{- Add New Company Insurance}

The purpose of "Add New Company Insurance Data" is to add a new employee as a member of Company Insurance the database. Not only does medical insurance form the government, but the company also provides company insurance from private company insurance. Therefore, this input is provided for employees that want to register themselves or the family members as the company insurance member. Figure 13 shows this menu

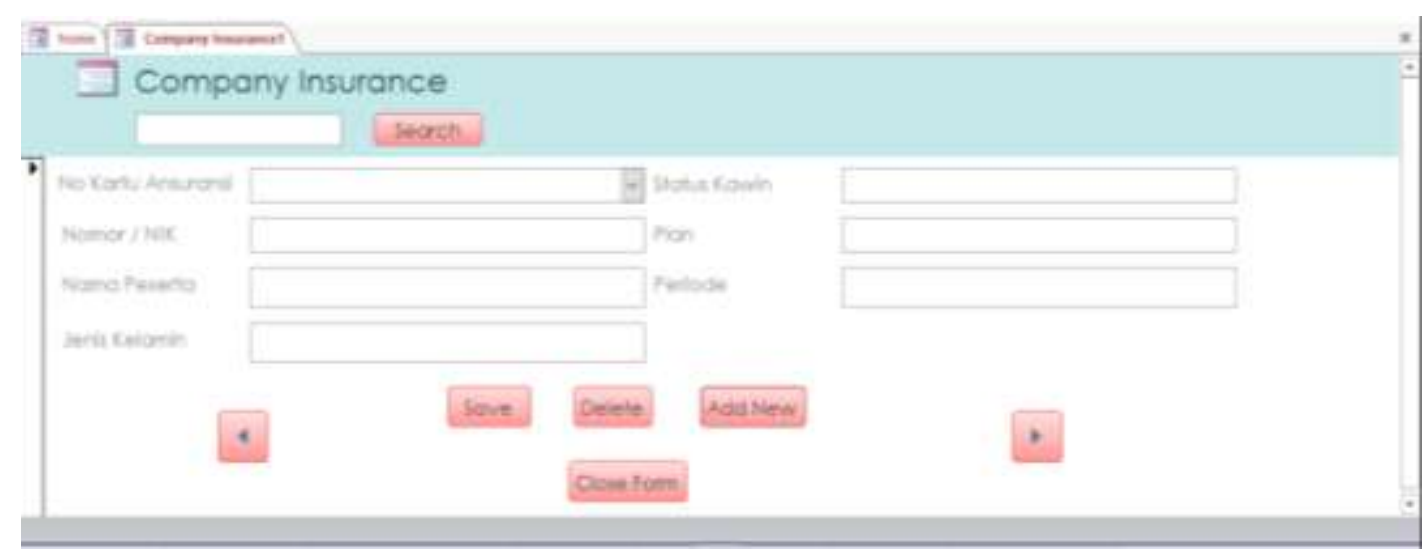

Figure 13. Add New Company Insurance

\section{- Reimbursement Claim}

Figure 14 shows a menu of "Reimbursement Claim" is to reimburse claim of money that has been paid by the employee for medical insurance and that can claim the money by the company. Employees can reimburse claims if the company insurance card has a limit when payment of medication that pays for the shortfall by the employee, the money can be reimbursed with the company but the employee must fill in the claim form and submit proof of payment. Reimbursement claims can be paid through employee salaries. 


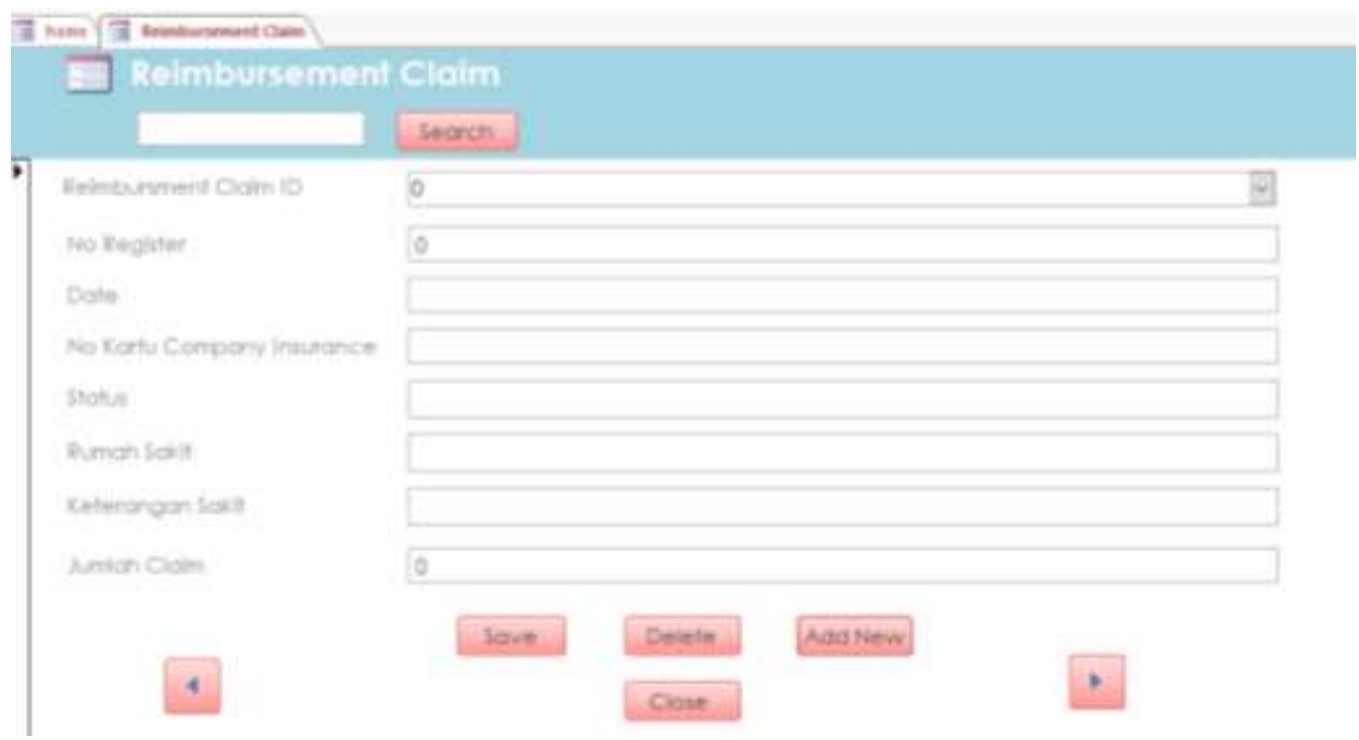

Figure 14. Reimbursement Claim

\section{- Billing Statement}

Figure 15 shows a menu of the "Billing Statement" to make statements that will be paid by the company for reimbursement claims, the statement will be submitted to finance to move the reimbursement of employee money into salaries. If the statement has been completed sending to finance, then the finance will be processed and bring evidence to the HR Department that the money has been reimbursed. The HR Department will input the report into the database that the billing statement has been paid for reimbursement.

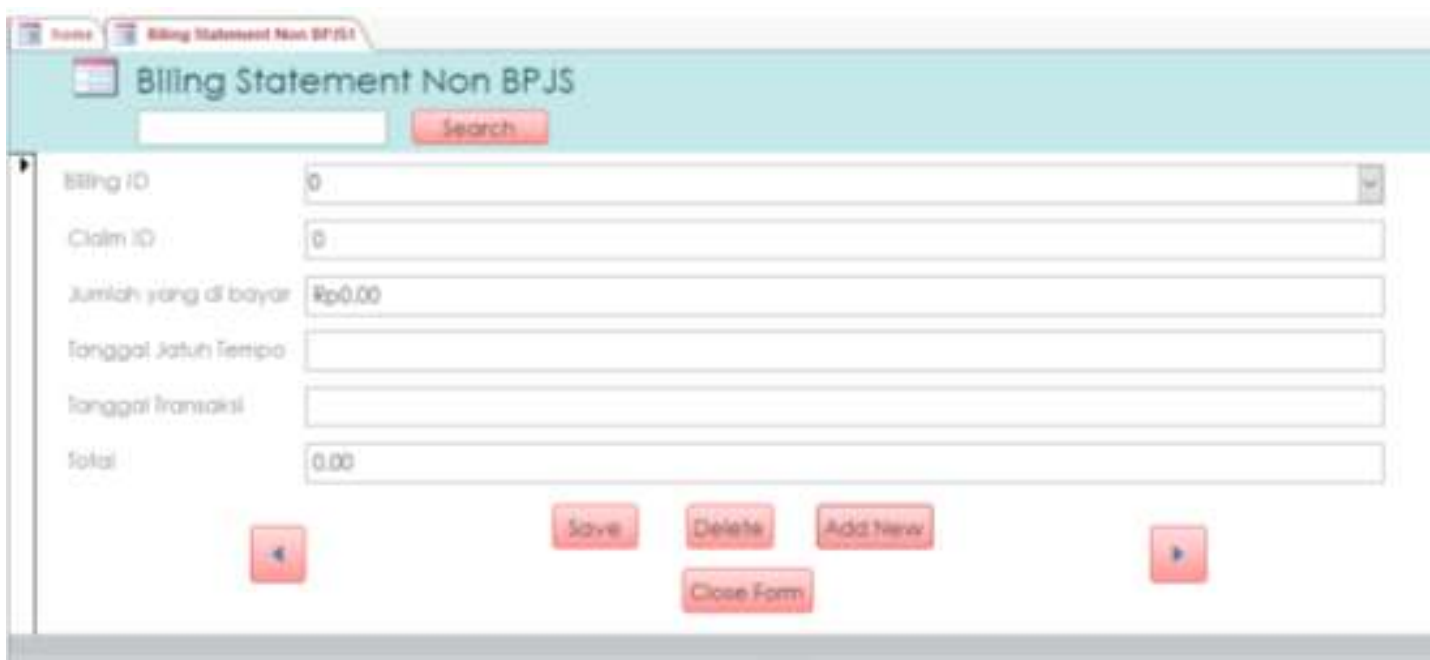

Figure 15. Billing Statement

\subsection{Development}

The development process is another critical process for the business process improvement since it will determine the success of the business process improvement. It will also determine the performance of the proposed system. Since the database is designed using MS Access, the software documentation will be formatted in MS Access. There are several formats in MS Excel to be converted and develop into the database. It also includes software documentation and a user manual. 


\subsection{Testing and Deployment}

Testing is the last phase of the Software Development Life Cycle before the software is delivered to customers or deployed. In this phase, the software is tested to ensure that it fulfills all requirements. In this phase, a testing scenario is prepared. It will test all parts of the software. The testing procedure is to verify each component's function of the database. By checking (eg: combo, command button, etc) to see if the actual outcomes of the test are the same as the expected. Table 1. provides comments and feedback as a result of such testing.

This phase involves the software being installed on a user computer. Software sometimes requires a user-end configuration for post-installation. To run the developed and tested software requires all the hardware and software specifications. Software is tested for portability, and during implementation, adaptability is resolved. It also requires program training for the user to function efficiently.

Table 1. Testing

\begin{tabular}{|c|c|c|c|c|}
\hline No & Feature & Test Scenario & Expected Result & Status \\
\hline 1 & Login & $\begin{array}{c}\text { Enter Valid User and } \\
\text { Password } \\
\text { Enter Invalid User and }\end{array}$ & $\begin{array}{l}\text { Load the database and display the main menu } \\
\text { Display message "Sorry have no registered / }\end{array}$ & OK \\
\hline 2 & & Password & Incorrect" & OK \\
\hline 3 & Exit & $\begin{array}{c}\text { Click Exit } \\
\text { Display "Add Employee" }\end{array}$ & $\begin{array}{l}\text { Exit from database and database } \\
\text { automatically out }\end{array}$ & OK \\
\hline 4 & Main Menu & $\begin{array}{l}\text { menu } \\
\text { Display "Add family }\end{array}$ & $\begin{array}{l}\text { Display input add employee data form } \\
\text { Display input add family membership data }\end{array}$ & OK \\
\hline 5 & & $\begin{array}{l}\text { Membership" menu } \\
\text { Display "BPJS Membership" }\end{array}$ & form & $\mathrm{OK}$ \\
\hline 6 & & $\begin{array}{l}\text { menu } \\
\text { Display "Company }\end{array}$ & Display input BPJS membership data form & $\mathrm{OK}$ \\
\hline 7 & & $\begin{array}{l}\text { Insurance" menu } \\
\text { Display "Reimbursement }\end{array}$ & $\begin{array}{l}\text { Display input Company Insurance data form } \\
\text { Display input Reimbursement Claim data }\end{array}$ & $\mathrm{OK}$ \\
\hline 8 & & $\begin{array}{l}\text { Claim" menu } \\
\text { Display "Billing Statement" }\end{array}$ & form & OK \\
\hline 9 & & menu & Display input Billing Statement data form & OK \\
\hline 10 & & Display "Report" menu & Display Billing Statement Report & OK \\
\hline 11 & & Display "Logout" menu & Back to the login menu & OK \\
\hline & Add New & & & \\
\hline 12 & Employee & Section "Save" button & Save new employee membership & OK \\
\hline 13 & & Section "Delete" button & $\begin{array}{l}\text { Delete employee membership } \\
\text { Add a new record for fill employee }\end{array}$ & OK \\
\hline 14 & & Section "Add New" button & membership & OK \\
\hline 15 & & $\begin{array}{l}\text { Section "Close" button } \\
\text { Section "Go to previous" }\end{array}$ & Close add employee form & OK \\
\hline 16 & & button & Go to previous employee membership data & OK \\
\hline 17 & & Section "Go to next" button & Go to next employee membership data & OK \\
\hline 18 & $\begin{array}{l}\text { Add Family } \\
\text { Membership }\end{array}$ & Section "Save" button & Save new family membership & OK \\
\hline 19 & & Section "Delete" button & Delete family membership & OK \\
\hline 20 & & Section "Add New" button & Add a new record for fill family membership & OK \\
\hline 21 & & $\begin{array}{l}\text { Section "Close" button } \\
\text { Section "Go to previous" }\end{array}$ & Close add family form & OK \\
\hline 22 & & button & Go to previous family membership data & OK \\
\hline 23 & & Section "Go to next" button & Go to next family membership data & OK \\
\hline 24 & $\begin{array}{c}\text { BPJS } \\
\text { Membership }\end{array}$ & Section "Save" button & Save new BPJS membership & OK \\
\hline 25 & & Section "Delete" button & Delete BPJS membership data & OK \\
\hline 26 & & Section "Add New" button & Add a new record for fill BPJS membership & OK \\
\hline 27 & & $\begin{array}{l}\text { Section "Close" button } \\
\text { Section "Go to previous" }\end{array}$ & Close add BPJS membership form & OK \\
\hline 28 & & button & Go to previous BPJS membership data & $\mathrm{OK}$ \\
\hline
\end{tabular}




\begin{tabular}{|c|c|c|c|c|}
\hline No & Feature & Test Scenario & Expected Result & Status \\
\hline 29 & & Section "Go to next" button & Go to next BPJS membership data & OK \\
\hline & Company & & & \\
\hline 30 & Insurance & Section "Save" button & Save new company insurance & OK \\
\hline 31 & & Section "Delete" button & Delete company insurance data & OK \\
\hline 32 & & Section "Add New" button & Add a new record for fill company insurance & OK \\
\hline 33 & & Section "Close" button & Close add company insurance form & OK \\
\hline 34 & & $\begin{array}{l}\text { Section "Go to previous" } \\
\text { button }\end{array}$ & Go to previous company insurance data & OK \\
\hline 35 & & Section "Go to next" button & Go to next company insurance data & OK \\
\hline & Reimbursement & & & \\
\hline 36 & Claim & Section "Save" button & Save new reimbursement claim & OK \\
\hline 37 & & Section "Delete" button & Delete reimbursement claim data & OK \\
\hline 38 & & Section "Add New" button & $\begin{array}{l}\text { Add a new record for fill reimbursement } \\
\text { claim }\end{array}$ & OK \\
\hline 39 & & Section "Close" button, & Close add reimbursement claim form & OK \\
\hline 40 & & $\begin{array}{l}\text { Section "Go to previous" } \\
\text { button }\end{array}$ & Go to previous reimbursement claim data & OK \\
\hline 41 & & Section "Go to next" button & Go to next reimbursement claim data & OK \\
\hline 42 & $\begin{array}{l}\text { Billing } \\
\text { Statement }\end{array}$ & Section "Save" button & Save new billing statement & OK \\
\hline 43 & & Section "Delete" button & Delete billing statement data & OK \\
\hline 44 & & Section "Add New" button & Add a new record for fill billing statement & OK \\
\hline 45 & & Section "Close" button & Close add billing statement form & OK \\
\hline 46 & & $\begin{array}{l}\text { Section "Go to previous" } \\
\text { button }\end{array}$ & Go to previous billing statement data & OK \\
\hline 47 & & $\begin{array}{l}\text { Section "Go to next" button } \\
\text { Display billing statement }\end{array}$ & Go to next billing statement data & OK \\
\hline 48 & Report & report & $\begin{array}{l}\text { Print the report of the billing statement } \\
\text { Sending by email the report of the billing }\end{array}$ & OK \\
\hline 49 & & & statement & OK \\
\hline 50 & Log Out & Log out the main menu & Display login menu & OK \\
\hline
\end{tabular}

\section{Conclusion}

The manual process for managing health insurance data at PT. X causes an error in data input, which results in delays in the process because it has to wait for confirmation from the health insurance provider. In many cases, delays in reimbursement claims due to manual data input and calculation processes spend a lot of time and energy. The result of the implementation is an application that runs on MS Access that can simplify data input and processing. Some features of the application are if HR Department forgets to click the save button then the application will automatically save the data, generate automatic data reports, export billing statement statements to MS Excel, and converting data to PDF. The application can manage medical insurance more efficiently and effectively, compared to previous MS Excel.

\section{References}

Azwir, H. H., \& Patriani, O. (April de 2017). Perbaikan Pengelolaan Pergudangan Melalui Penerapan Sistem Informasi Pergudangan di CV. ABB. Jurnal Optimasi Sistem Industri, 16(1), 10-24.

Azwir, H. H., \& Puspa, G. D. (Mei de 2020). Development Of Application For Managing Jobs And Documentation Relating To Occupational Health And Safety In A Toys Company. J@TI, 15(2), 93-101.

Barjtya, S., Sharma, A., \& Rani, U. (2017). A detailed study of Software Development Life Cycle (SDLC) Models . International Journal Of Engineering And Computer Science , 22098.

Buzkan, H. (March de 2016). The Role of Human Resource Information System (HRIS) in Organizations. Academic Journal of Interdisciplinary Studies, 133. 
Halseth, K. (2017). Process Modelling \& Mapping: The Basics. David Thompson Health Region. Kendall, K. E., \& Kendall, J. E. (2019). System Analysis and Design (10th ed.). United States of America: Pearson.

Khosravi, A. (2016). Business process rearrangement and renaming: A new approach to process orientation and improvement. Business Process Management.

Sharma, M. K. (2017). A study of SDLC to develop well-engineered software. International Journal of Advanced Research in Computer Science, 521.

Valacich, J. S., \& George, J. F. (2017). Modern Systems Analysis and Design (8th ed.). USA: Pearson Education.

Zemguliene, J., \& Zemguliene, M. (2018). Structured literature review on business process performance analysis and evaluation. Entrepreneurship and Sustainability Issues, 3. 
[ Halaman kosong ] 